\title{
DASAR-DASAR KONFLIK DAN MODEL RESOLUSI KONFLIK PADA MASYARAKAT DESA PANTURA J ABAR
}

\author{
M.Munandar Sulaeman \\ Staf Pengajar Laboratorium Sosiologi Penyuluhan Fapet, \\ Pascasarjana FISI P Unpad \\ E-mail:mar_sul@yahoo.com
}

\begin{abstract}
ABSTRAK. Tujuan dari penelitian ini adalah mengetahui apa prasyarat kondisi konflik dan dasar-dasar konflik; Bagaimana keterkaitan nilai sosial budaya atau tradisi dengan terjadinya konflik antar warga dan resolusi konflik. Metode penelitian adalah studi kasus pendekatan kualitatif; Informan diambil secara purposive. Hasil penelitian : Prasyarat kondisi yang mencukupi (sufficiency condition) konflik yaitu: Pertama tradisi minuman keras sebagai simbol hiburan hajatan, yang terlembagakan melalui kesenian tradisional. Kedua, akibat tingginya sensitivitas pribadi, krisis identitas dan harga diri yang menuntut perhatian. Dasardasar terjadinya konflik adalah adanya perbedaan atau kontradiksi orientasi nilai sosial dan degradasi pemaknaan nilai sosial budaya dan upacara tradisi. Nilai sosial budaya (tradisi ritual dan seni) memiliki potensi sebagai modal sosial perdamaian karena sifatnya dapat memotivasi dan menumbuhkan perdamaian serta kondusif menggalang dan menumbuhkan kerjasama, tanggungjawab, penyelesaikan masalah bersama, meluaskan jaringan hubungan sosial, rasa solidaritas sosial dan kejujuran. Pemerintah dan masyarakat harus menumbuhkan nilai sosial budaya damai dan harmoni dengan sistem kondusif yang mengaktualisaskan dan merevitalisasi seni dan upacara tradisional melalui pencerahan rasional, logis dan agamis serta professional.
\end{abstract}

Kata kunci: Dasar Dasar Konflik, Resolusi Konflik.

\section{BASES OF CONFLICT AND CONFLICT RESOLUTION MODELS I N RURAL SOCI ETY PANTURA J ABAR}

\begin{abstract}
The purpose of this study was to determine what prerequisite conditions of conflict and the base of the conflict; How to link socio-cultural values or traditions with the occurrence of conflicts among residents and conflict resolution. The research method is qualitative case study approach; Informants were taken purposively. Results: Pre-requisite conditions sufficient (sufficiency condition) conflict, namely: First tradition of hard liquor as a symbol of a celebration of entertainment, which institutionalized through traditional arts. Second, due to high personal sensitivity, self-esteem and identity crisis that demands attention. The basics of conflict or contradiction is the difference of social value orientation and the degradation of social values and cultural meanings ceremonial tradition. Socio-cultural values (tradition of ritual and art) have potential as a social capital of peace because it is able to motivate and cultivate a
\end{abstract}


conducive and build peace and foster cooperation, responsibility, settlement problems together, broaden the network of social relationships, a sense of social solidarity and honesty. Government and community should foster social and cultural values of peace and harmony with a system conducive to mengaktualisaskan and revitalize traditional art and ritual through enlightenment rational, logical, and religious and professional.

Keywords: Basic Basic Conflict, Conflict Resolution.

\section{PENDAHULUAN}

Konflik antar warga masyarakat di pedesaan pantai Utara Jawa Barat telah mengakibatkan kerugian material maupun jiwa dan aspek psikologis masyarakat. Data pada periode tahun 2001 sampai 2002 telah terjadi konflik pada saat hajatan 7 kali $(63,6 \%)$, perselisihan biasa 2 kali $(18,2 \%)$, akibat kasus pemalakan 1 kali $(9,1 \%)$ dan akibat lemparan 1 kali $(9,1)$. Kemudian pada tahun 2004 dan tahun berikutnya terjadi beberapa kali konflik pada saat pemilihan kepala desa. Hal demikian menunjukkan rawannya masyarakat untuk terjadinya konflik tawuran, sehingga menimbulkan dugaan adanya aspek lain yang berkaitan nilai sosial budaya tentang akar masalah konflik.

Masalah konflik di pedesaan tidak dapat dipisahkan dari faktor internal: kepentingan individu atau kelompok aspek kekuasaan, ekonomi dan nilai serta lemahnya sumberdaya manusia dan modal sosial. Aspek kepentingan kekuasaan realitasnya tampak pada konflik pilkades dan ketersinggungan harga diri sehingga muncul konflik antar pemuda yang merembet ke seluruh warga. Konflik nilai terkait dengan budaya kesenian hiburan (selesai panen) pada hajatan sebagai rangkaian dari sistem kehidupan bertani. Faktor ekternal: lemahnya aparat keamanan dan organisasi sosial kemasyarakatan dalam mengintegrasikan masyarakat dan memelihara pranata atau tradisi dan modal sosial, sehingga terjebak pada peristiwa konflik.

Aspek teoritis konflik banyak pandangan sehingga mengkaji konflik dapat dilihat dari berbagai sisi atau mengkaji berdasarkan pandangan, sehingga hasilnya akan lebih luas. Untuk kajian konflik kasus di Pantura yang relevan sebagai rujukan di antaranya adalah kajian dari sosiolog klasik Simmel, Weber dan Collins. Simmel mengangkat teori konflik dari bentuk dasar proses sosial yang bersifat empirik, sebagai sesuatu yang tidak dapat dielakan, akibat struktur sosial yang mendominasi, tetapi tetap tidak terpisahkan dari proses asosiatif dan disosiatif (kecenderungan sifat masyarakat monistik dan antagonistik). Hal ini dijelaskan Simmel (1964) :

Konflik merupakan suatu keharusan, jika kelompok yang tersubordinasi secara keseluruhan terinternalisasi dan unsur-unsur superordinasi melaksanakannya sebagai kekuatan moral ideal, sebagai tuntutan yang bersifat individual serta situasinya jelas. Kewajiban atau perilaku berkonflik merupakan dasar untuk kebebasan penuh bagi subyek, sebab hanya dengan kebebasan yang dapat 
mengakui dan taat terhadap dua tuntutan (pembebasan dan integrasi) sebagai suatu kewajiban moral.

Konflik memiliki dualisme tujuan yaitu tujuan integrasi dan tujuan pembebasan diri, gengsi dan kerusakan, selain itu juga dalam rangka pemeliharaan proses, pengaturan organisasi dan solidaritas. Asumsi konflik menurut Simmel bahwa: pelibatan emosi dalam kelompok konflik akan memperhebat konflik, penghargaan yang tinggi tehadap solidaritas dari kelompok konflik akan memperhebat pelibatan emosi dalam konflik, demikian pula konflik meningkat searah dengan peningkatan akan tujuan dan kepentingan. Asumsiasumsi yang diajukan Simmel akan membantu dalam menganalisis proses sosial (konflik) baik konflik vertikal maupun horisontal. Kemudian muncul pandangan teori konflik dari Max Weber, yang orientasinya lebih kepada stratifikasi dan perubahan sosial (Turner, 1991:196). Pandangan Weber tentang konflik, dijelaskannya sebagai berikut.

Suatu hubungan sosial akan mengarah kepada konflik, sejauh merupakan tindakan intensional dan terorientasi, yang mendorong munculnya para aktor yang sepantasnya mendapat tantangan dan perlawaan dari pihak (kelompok/golongan) lain. Kegiatan Individu-individu dalam mengambil posisi, atau jenis status sosial lain untuk memperoleh keuntungan dalam kehidupannya adalah sering bersifat laten atau tidak tampak, tetapi dengan orientasi untuk tidak saling memberi makna yang sama, maka ada dalam terminologi konflik. (Eldridge, 1980:85).

Substansi konflik bagi Weber ada dalam kerangka hubungan sosial yang bersifat intensional dan adanya perbedaan orientasi, yaitu untuk tidak saling memberi makna yang sama, sebagai pertarungan laten untuk memperoleh kedudukan dan status sosial (harga diri) demi kehidupannya. Menurut Raymond Aron (1965), pandangan Weber menganggap konflik sebagai proses interaksi sosial, sebagai keinginan dari masing-masing partisipannya untuk saling menjatuhkan dari menjaga kelangsungan daya tahan masing-masing.

Sumbangan Weber terhadap teori konflik adalah bahwa Weber menambahkan kompleksitas teori konflik, sumber konflik kepentingan banyak dan termasuk pengawasan pada organisasi. Bidang lain adalah perjuangan mengontrol "barangbarang produksi emosi", untuk legitimasi dan usaha dominasi. Mekanisme produksi emosi merupakan alat utama yang digunakan dalam konflik. Melalui "ritual emosi" dapat digunakan sebagai dominasi suatu organisasi, kesadaran mereka membawa kepada aliansi kelompok (solidaritas sosial) untuk menentang kelompok lain dan meruntuhkan hirarki dari status prestasi. Weber menyusun semua aspek dominasi melalui manipulasi solidaritas emosi, sehingga meliputi banyak bentuk stratifikasi komunitas berdasarkan budaya (Collins, 1975: 58-59). Pada kasus konflik tawuran pemuda, sering terjadi karena adanya manipulasi solidaritas emosi. Artinya pelaku 
tidak memikirkan siapa yang ada di posisi benar atau salah, yang menjadi perhatiannya hanyalah pada solidaritas emosi.

Dasar teori konflik menurut Collins (1975: 56-61) interaksi antar pribadi bersifat intensif, yang dalam kenyataanya bersifat abstrak dan kompleks, sehingga diperlukan level analisis lain. Maksudnya perilaku individu perlu dijelaskan dalam konteks kepentingan pribadi akan dunia materi, yang tampak dalam keteraturan sosial sebagai tekanan dan pemaksaan organisasi, demi kepentingan kelompok. Secara fenomenal konflik tawuran di antaranya disebabkan oleh persoalan individu yang jelas, dimana motivasi dan tujuan tidak tercapai. Sedangkan akar masalahnya atau kondisi yang mendasarinya adalah besarnya kemiskinan, pengangguran, dan secara umum akibat kerusakan kondisi kehidupan sosial.

Adanya variasi teori konflik, memberikan peluang untuk mengkaji substansi konflik lebih mendalam dan dapat memprediksi berbagai konflik yang akar permasalahannya bermacam-macam. Demikian pula hasil kajian tentang konflik pedesaan telah dilakukan oleh beberapa peneliti di antaranya tentang konflik antar kelembagaan pemerintahan (kepala desa) dengan lembaga atau Badan Perwakilan Desa (BPD), yang nyaris tidak terdamaikan (Cahyono, 2005). Konflik tersebut fokusnya pada perbedaan kepentingan dan orientasi paham kedaulatan rakyat yang lebih kuat pada BPD, dibandingkan dengan kepala desa. Kajian lain tentang konflik di pedesaan berkaitan dengan kemiskinan dan keterbatasan sumber daya perikanan (Kusnadi, 2002). Kajian tersebut berbeda dengan kajian koflik antar warga yang lebih multi dimensi, berkaitan dengan aspek emosional, persaingan pengaruh dan dan interaksi sosial yang disosiatif dalam media hiburan, sehingga akan mengungkap berbagai unsur penyebab konflik. Demikian pula lingkup wilayah penelitian yang dilakukan di Pantura J awa Barat, akan memberikan banyak variasi proses konflik karena banyak unsur ritual.

Mengenai resolusi konflik dalam kenyataan banyak dilakukan dengan cara represif, dan jarang dilakukan dengan memanfaatkan potensi pengetahuan lokal. Teori resolusi konflik dikembangkan dari teori atau pendekatan konflik itu sendiri. Miall, Ramsbotham dan Woodhouse (2000:7-33), menawarkan banyak alternatif tentang resolusi konflik, mulai dari pemikiran klasik sampai pada pemikiran kontemporer Pemikiran resolusi konflik berangkat dari asumsi bahwa konflik sebagai aspek intrinsik yang tidak mungkin dihindarkan dari perubahan sosial. Konflik diartikan sebagai ekspresi heterogenitas kepentingan, nilai dan keyakinan yang muncul sebagai formasi baru yang ditimbulkan oleh perubahan sosial yang muncul bertentangan dengan berbagai hambatan yang dihasilkannya. Namun cara menangani konflik adalah persoalan kebiasaan dan pilihan, sehingga perlu merespon cara menangani konflik tersebut.

Permasalahan penelitiannya adalah seperti berikut:

(1) Apa dasar-dasar konflik atau akar masalah konflik yang terjadi pada masyarakat pedesaan sehingga menimbulkan kerusuhan sosial antar warga masyarakat, antar kampung atau antar desa?

(2) Sejauhmana potensi nilai sosial budaya perdamaian penyelesaian 
konflik termasuk modal sosialnya yang ada dalam masyarakat?

\section{METODE}

Penelitian dilakukan di pantai Utara Jawa Barat (Kabupaten Indramayu dan Subang) dengan batas lingkupnya pada wilayah kecamatan atau desa yang terjadi kasus konflik kerusuhan paling tinggi frekuensinya (antara tahun 2000-2002). Penelitian ini dilakukan dengan studi kasus yaitu mempelajari peristiwa konflik dengan menggali data kualitatif, yang meliputi proses konflik secara menyeluruh (holistik) dan dibuat deskripsi secara prosesual tentang terjadinya konflik, mengungkap simbol atau makna dari tindakan konflik yang terjadi, berupa ungkapan atau pernyataan dan perasaan subyek, mulai dari pertikaian antar individu serta kondisi sosial budayanya. Pengambilan data difokuskan pada alasan mengapa terjadi konflik tawuran, juga tahapan terjadinya konflik berupa peristiwa yang timbul dalam konflik tersebut. Informan atau subyek penelitian dipilih sesuai tujuan penelitian (purposive) yang terdiri dari para pemuda dan remaja pelaku konflik, tokoh masyarakat: kepala desa, staf pengurus desa, kepala urusan (kaur) pemerintahan, sekdes, para guru, tokoh agama (ustad) juga aparat kepolisian baik dari Polsek maupun Polres. Informasinya dikembangkan secara bola salju (snow bal/) mulai dari informan sekunder (yang tidak langsung terlibat konflik) sampai ke pelaku konflik, sebagai informan primer. Analisis dengan cara pemahaman mendalam (understanding, verstehen) baik secara tekstual maupun kontekstual, yang kemudian di interpretasikan. Kontrol data melalui dialogis antar fakta dengan pendapat tokoh formal dan informal terpercaya, diskusi di laboratorium, memerikasa informasi dari beberapa pelaku konflik dan memeriksa hasil kajian pemda pada kasus yang sama (model triangulasi).

\section{HASI L DAN PEMBAHASAN \\ Keadaan umum masyarakat}

Masyarakat Indramayu dan Subang (bagian Utara) hampir mirip yaitu mempunyai karakter nilai sosial budaya yang spesifik apabila dibandingkan dengan kabupaten lainnya di Jawa Barat. Aspek kultur masyarakatnya pantai yang mempunyai nilai atau norma "longgar", seperti menganggap minuman keras sebagai kelengkapan dari suatu hajatan, artinya nilai-nilai yang diserap masyarakatnya adalah nilai yang variatif yang terobyektivisasi saat zaman pemerintahan kolonial Belanda (hasil wawancara dengan staf Dinas Pariwisata Subang, 2005). Fenomena yang tampak adalah budaya "hiburan" (pertunjukkan kesenian dalam bentuk kesenian tarling, dangdut/organ tunggal, tarling, sintren, sandiwara dan lainnya) dan kebiasaan minuman keras. Semua ini merupakan bagian dari pola kehidupan sosial masyarakat. Hal ini dapat dibuktikan pada setiap selesai panen selalu ada acara hiburan dalam rangka hajatan. Hiburan melalui hajatan tersebut adalah fungsional bagi kelembagaan masyarakat desa seperti upacara ritual pernikahan, sunatan, perayaan hari besar baik yang nasional maupun yang bersifat keagamaan seperti syukuran panen, sedekah laut atau 
selesai membangun fisik (rumah, kantor, jalan, jembatan). Orientasi pada hajatan demikian mempunyai pengaruh terhadap kultur ekonomi masyarakat. Mereka berfikir bahwa apa yang diperoleh secara ekonomi tunduk pada kepentingan ritual (nilai) sosial budaya baik yang sifatnya acara hiburan maupun upacara adat, maka nilai ekonomi mereka tidak berorientasi pada kepentingan peningkatan produktivitas masa depan, tetapi terdominasi oleh kepentingan orientasi nilai sosial budaya tersebut. Kegiatan ekonomi seperti usaha tani lebih termotivasi oleh budaya hajatan plus hiburan seni atau oleh nilai upacara tradisional. Artinya prestasi usaha tani meningkat karena harapan dapat melangsungkan hajatan dan hiburan, juga oleh keyakinan terhadap ritual tradisional. Hal demikian dapat pula sebagai bentuk dari adanya apresiasi masyarakat dan potensi nilai seni lokal serta upacara tradisional milik mereka.

Fenomena pemahaman agama dapat ditunjukkan oleh pola aktivitas kelembagaan agama. Pada masyarakat wilayah pedesaan yang banyak diamati konflik, pemahaman terhadap substansi agama masih kurang, hanya sebatas rutinitas, kurang terefleksikan dalam kehidupan sehari hari. Khusus mengenai hiburan dalam rangka hajatan, ternyata merupakan medan sosial yang mempunyai daya magnit tinggi, bukan hanya bagi kaum remaja, tetapi juga orang tua. Hiburan dengan segala perangkatnya bagi petani kaya sudah merupakan bagian sistem sosial masyarakat petani, artinya fungsional tidak terpisahkan dan selalu dilakukan setelah panen raya.

Konflik antar warga Kampung/Desa.

Berdasarkan hasil kajian tentang konflik, tawuran antar kampung atau antardesa pada umumnya terkait dengan dua unsur penting yaitu: keterlibatan emosi dalam konflik dan tingginya rasa solidaritas pada komunitas kampung dan desa. Unsur tingginya emosi dipacu oleh kondisi umum pelaku konflik dalam keadaan mabuk, yang memancing emosi atau kemarahan baik yang mabuk atau tidak mabuk. Tingginya rasa solidaritas antar keluarga yang dilembagakan melalui nilai tradisi, di antaranya tradisi kerjasama dalam memenuhi kebutuhan hajatan yang disebut dengan "buwuhan". Apabila ada keluarga anggota "buwuhan", terlibat dalam konflik akibat tindakan pihak lain, maka anggota lainnya akan mudah terpancing dan terlibat konflik. "Buwuhan" adalah istilah setempat untuk kelembagaan tolong menolong dalam memenuhi kebutuhan hajatan atau membantu yang terkena musibah dengan memberikan sumbangan, biasanya hasil panen padi baik secara pamrih atau tidak pamrih, yang berfungsi secara sosial, ekonomi dan budaya Sehingga untuk wilayah pedesaaan pola ekologi sawah di Indramayu berlaku proposisi bahwa konflik tawuran di pedesaan akan meningkat apabila ada keterlibatan emosi dan besarnya potensi solidaritas di antara warga masyarakat desa atau kampung (sesuai dengan tesis George Simmel).

Konflik di kabupaten Subang tidak hanya tawuran akibat dari adanya hiburan hajatan, tetapi akibat persaingan pada pemilihan kepala desa. Antusias masyarakat pada pemilihan kepala desa begitu tinggi, bahkan pemilihan kepala desa menjadi ajang taruhan penjudi. Pada saat pemilihan desa muncul unjuk kekuatan baik 
secara fisik, spiritual maupun materi. Unjuk kekuatan selain dengan tindak kekerasan juga ancaman apabila tidak memilih seseorang (meskipun dengan jujur), sehingga hal demikian ini merupakan pemerasan.

Konflik akibat orientasi prestise, yaitu konflik yang terjadi apabila harga diri seseorang direndahkan di depan umum, seperti tersinggung oleh perkataan atau tindakan saat hiburan. Hal demikian terjadi pada para remaja dan pemuda yang telah berselisih dan mendapat penganiyaan dari salah seorang teman sekampung atau sedesa, menyebabkan kelompoknya hilang harga diri. Konflik tawuran dapat pula terjadi akibat kehilangan kewenangan, menyebabkan harus mempertahankan harga dirinya atau kelompoknya, seperti perselisihan di tempat hiburan atau di kampung akibat rebutan teman gadis. Kasus seperti ini terjadi pada konflik di desa wilayah KabupatenSubang. Berbeda dengan tahapan proses konflik tawuran di tempat hiburan, tahapannya begitu cepat. Konflik dimulai dari adanya persoalan pribadi yang disebabkan oleh beragam sebab, bisa karena terinjak atau kena sikut saat joget, salah kata-kata yang menyinggung perasaan, berebut teman joget (perempuan) dan saingan dalam pacaran. Persoalan yang tidak dapat diselesaikan di tempat, dapat langsung menimbulkan adu fisik, setelah ada korban dari satu pihak, dilanjutkan dengan balas dendam, maka terjadilah tawuran masal, yang didorong oleh rasa solidaritas terhadap teman sekampung atau sedesa. Sehingga tampak bahwa eskalasi konflik tawuran lebih cepat dibandingkan dengan eskalasi konflik pemilihan kepala desa.

Kronologi Proses Konflik

Kronologi proses konflik di beberapa desa hasil wawancara dengan beberapa informan dan dari penelusuran data sekunder dipaparkan beberapa kasus sebagai berikut :

(1). Kecamatan Gabus Wetan dan Kecamatan Kandang Haur : Kasus Konflik Tawuran Antar Desa Drunten Wetan dan Kulon (Kecamatan Gabus Wetan); Antara Desa Drunten dengan Desa Curug (Kecamatan Kandang Haur)

Kronologi kejadiannya sebagai berikut:

Pada hari Selasa tgl 10-9-2002 pada pukul 2 malam telah terjadi tawuran antara warga Desa Curug Kacamatan Kandanghaur dengan warga Desa Drunten Wetan Kecamatan Gabus Wetan yang terjadi di Desa Pranti Kecamatan Kandanghaur. Alat tawuran berupa batu bata. Keributan dilatarbelakangi oleh adanya hiburan organ tunggal di Desa Pranti. Korbannya adalah seorang warga Drunten Wetan menganlami luka bacok. Jumlah peserta tawuran mencapai 250 orang.

Selain itu warga Desa Drunten Wetan juga tawuran dengan Desa Drunten Kulon yang terus terjadi secara bergelombang, sehingga mencapai permusuhan yang lama dan sering terjadi konflik. Kronologisnya : Pada hari Selasa malam tanggal 29 Mei terjadi tawuran antara dua warga desa tersebut, yang diwarnai dengan perang anak panah, yang menyebabakan belasan warga menderita luka anak panah dan luka petasan. Penyebab dari tawuran dimulai pada saat adanya hiburan organ tunggal ditempat hajatan. Akibat lain 
dari tawuran, 150 siswa SLTP tidak dapat mengikuti ebtanas dan harus diulang. Karena tawuran antar desa tersebut terjadi secara bergelombang, maka warga yang bersangkutan berusaha mencari penyelesaiannya (pada hari Rabu tanggal 6 J uni 2001) dengan cara melaksanakan upacara "Luar Biasa J embatan Karang Asem" yang dilanjutkan dengan makan nasi tumpeng bersama (dalam istilah setempat disebut "brayan") di atas jembatan Asem perbatasan kedua desa tersebut dengan disaksikan oleh sekitar 500 orang terdiri dari para pelaku tawuran, para tokoh masyarakat, aparat desa (Kepala Desa, BPD dan LPM) dan Tripika (Camat, Kapolsek, Danramil) setempat. Pada acara penyelesaian tersebut diambil kesepakatan bahwa :

(a) Mengharamkan tawuran yang sudah banyak korban harta dan jiwa.

(b) Apabila dua bulan setelah perjanjian tidak terjadi tawuran lagi, maka akan dilakukan syukuran dengan makan bersama lagi.

(c) Namun apabila dari kedua pihak ada yang melakukan tawuran lagi maka masyarakat akan menghukum.

Kesepakan tersebut ditandatangani di atas segel oleh kedua belah pihak. Tetapi ditekankan yang penting perjanjian dengan hati yang sungguh-sungguh, sehingga surat diatas segel tidak diperlukan lagi. Demikian ikrar penyelesaian konflik. Ketua BPD menyatakan " bahwa nasi tumpeng yang dimakan merupakan saksi abadi bahwa kedua belah pihak tidak akan melakukan tawuran lagi. Jika melanggar maka pelakunya akan mendapat kutukan.".

Masih di Kecamatan Gabus Wetan, terjadi tawuran tanggal 16 September 2002, pada pkl. 22.45. antar warga Desa Kedungdawa Kecamatan Gabus Wetan dengan warga Desa Cipedang Kecamatan Bongas peserta 200 orang dan pelaku 24 orang .terjadi di lokasi hiburan organ tunggal di di Desa Cipedang. Korban kerusakan 16 rumah dan 10 lampu penerangan. Dan dua orang kena luka bacok.

(2). Kecamatan Sliyeg: Kasus Konflik Tawuran antara Desa Tugu dan Desa Gadingan, Segeran, Singaraja, Sudimampir Kecamatan Sliyeg.

Kronologis konfliknya sebagai berikut:

Seseorang warga Tugu kebetulan istri mudanya di desa Mekar Gadingan menyelenggarakan hajatan sunatan dan acara lebaran yang disertai acara pesta "minum". Entah bagaimana mulainya, tiba-tiba seorang warga Tugu kepalanya terkena pukulan botol minuman. Rasa solidaritas yang tinggi terhadap korban, maka warga Tugu menyerang pemuda warga Mekar Gadingan. Demikian halnya desa Gadingan yang sebelumnya masih satu desa dengan Mekar Gadingan melibatkan diri membantu warga Mekar Gadingan, Mekar Gadingan juga dibantu warga Sudimampir yang semula pernah konflik dengan warga desa Tugu. Sejak peristiwa tersebut terjadilah beberapa gelombang tawuran. Warga desa Tugu juga terlibat tawuran dengan desa yang berada di perbatasannya (di sekelilinginya) seperti dengan desa Segeran, Sudimampir dan Timpuh. Konflik tawuran disertai dengan senjata golok, bata, dan bom molotov bahkan karena dendam sampai jalan pun 
diputus dengan menggali parit. Warga Mekargading yang menjadi korban tawuran nekad merusak jalan diperbatasan kedua desa, merupakan jalan alternative penghubung Karangampel Jatibarang. Pengrusakan sebagai bentuk protes atas pembakaran dan penjarahan 25 rumah milik warga Mekargading oleh warga Tugu.

Upaya damai telah dilakukan beberapa kali dengan cara musyawarah antar tokoh masyarakat dan aparat desa BPD, LPM, Kuwu dan para pemuda. Sebagai simbol damai diperbatasan dipancangkan bendera putih. Namun hal ini juga kurang berhasil karena tawuran terjadi lagi. Bahkan sempat pula didamaikan di depan DPRD dengan disaksikan pihak kepolisian, tokoh masyarakat, aparat desa yang bersangkutan dan FORKAT (Forum Silaturahmi Masyarakat) sebagai LSM setempat.

\section{Tragedi perlawanan "nudis".}

Pernah pula sewaktu warga pemuda Tugu menyerang Mekargadingan mereka dihadapi oleh kaum ibu-ibu. Sekitar tiga puluh orang ibu-ibu siap menghadapi pemuda Tugu dengan menghadang di jalan pesawahan berjejer berbaris dengan hanya mengenakan kain tanpa baju. Kemudian pada saat pemuda Desa Tugu mendatangi masuk kewilayah Desa Mekargading dan berhadapan ibu-ibu, maka serta merta ibu-ibu langsung membuka kainnya, dan mereka pun para pemuda penyerang kembali, merasa dipermalukan oleh ibu-ibu. Inisiatif penghadangan oleh ibu-ibu ini juga ada motif kiat perlawanan melumpuhkan kedigjayaan (semacam kekebalan).

Penyelesaian konflik pada tahun 2000-2002, antar Desa Tugu dengan Desa tetangga lainnya sempat dilakukan dengan penegakan hukum ( law enforcement), melalui satuan "buru sergap" atau dikenal buser. Hal tersebut terjadi karena ada kecenderungan kelompok pemuda tawuran menjadi kelompok penekan aparat desa, sehingga aparat desa "terpaksa" menjadi pelindung pemuda, dilematis antara mengikuti kebijakan petugas keamanan dengan tekanan pemuda. Akhirnya secara tidak disadari Kepala desa dan lurah (sekertaris desa) menjadi bagian dari pemuda tawuran. Kepala desa dan Lurah (inisial S) sempat menjadi buruan tim "buru sergap", sampai kakinya kena tembak.

Sehubungan kasus tawuran Tugu, maka penyelesaian direspon Bupati dengan berkunjung dan berdialog dengan warga Mekargading dan Gadingan juga dengan tokoh masyarakat Tugu, serta memberikan santunan kepada korban yang disaksikan unsur Tripika. Komentar bupati:

"Prihatin dengan sikap emosional warganya yang hanya persoalan sepele menjadi tawuran. Lebih prihatin lagi tawuran cenderung dimanfaatkan untuk melakukan tindakan kriminal, pengrusakan, pembakaran, penjarahan serta pembunuhan. Kapan kita jadi masyarakat beradab, sulit bisa maju dan investor mana bias masuk kalau masyarakat memiliki budaya keras. Minta bersabar dalam menghadapi persoalan." 
Sehubungan dengan kasus konflik Desa Tugu, maka penyelesaian konflik juga dilakukan pemerintah setempat dengan pendekatan sosial-ekonomi, karena diduga adanya masalah kesenjangan sosial ekonomi masyarakat yang ada di sekitar kilang bahan bakar minyak Balongan. Kebijaknnya dengan mengikutsertakan sebagian warga menjadi buruh di kilang bahan bakar tersebut. Bahkan lurahnya (inisial G) yang dulu diduga sebagai pelindung kelompok pemuda tawuran, sekarang sudah menjadi pengusaha.

Desa Tugu yang menurut aparat dianggap paling rawan tawuran dicoba diantisipasi dengan cara menyalurkan kegiatan dengan olahraga sepakbola. Di Tugu diselenggarakan kompetisi Liga Sepakbola antar Blok yang berlangsung selama 35 hari yang diselenggarakan oleh Pembina masyarakat Tugu yang didukung Kapolsek.

(3). Kecamatan Arahan dan Kecamatan Catinggi: Desa Arahan Lor dan Arahan Kidul melawan Blok Nagrak Desa Linggar J ati. (Kecamatan Catinggi)

Kronologinya adalah sebagai berikut :

Pada hari Sabtu tgl 7 - 9 -2002, pk 8 malam terjadi tawuran antara warga Desa Arahan Kecamatan Arahan Lor dengan warga Desa Linggarjati bergabung dengan warga Desa Panyingkiran Kidul Kecamatan Catigi, tempatnya di Blok Cabang Desa Arahan Lor, pelakunya sekitar 74 orang berasal dari ketiga desa tersebut. Latar belakang keributan terjadi tawuran dipicu oleh hiburan organ tunggal. Senjata yang digunakan dalam tawuran ini meliputi 56 bom molotov dan lima buah senjata tajam . Akibat dari tawuran tersebut telah dibakar 29 rumah milik warga Desa Arahan lor, 27 buah rumah lainnya rusak. Perselisisihan sudah dimulai sehari sebelumnya pada hiburan tarling dangdut di sebuah hajatan di panyingkiran Kidul. Biasanya setiap kelompok pemuda menyampaikan mencuri perhatian (curhat) melalui para biduan dengan meminta lagu seraya memberikan uang "saweran". Maka terjadilah persaingan antar kelompok pemuda, kebetulan kelompok pemuda Nagrak (Linggarjati) lebih sering disebut-sebut karena uang sawerannya lebih besar. Kelompok pemuda Arahan merasa panas dan saat itu juga terjadi bentrokan namun masih dapat diredam. Malamnya menjadi tegang karena kedua belah pihak saling melempar merecon dan Molotov. Akhirnya tawuran meledak pemuda Nagrak menyerbu warga Arahan dengan menggunakan berbagai senjata tajam, sehingga 30 rumah terbakar dan lainnya rusak Warga Arahan bermaksud membalas serangan namun dapat cepat diatasi oleh petugas gabungan dari perintis, serse, satpol PP, lantas Polres, intel dan Kodim, dengan melakukan penyisiran atau "sweeping" sehingga diciduk 74 tersangka perusakan dan tawuran. Terbukti pelaku ada juga dari luar daerah seperti Cidampet, Penyingkiran Kidul dan Pecuk, diduga mereka membantu dan dibayar. Penanganannya 
Menurut salah seorang staf Polres bahwa:

“Tawuran ini cukup brutal sebab bom molotov tidak hanya dilempar ke musuhnya, juga ke aparat, malahan Danramil sampai luka kena lemparan Molotov. Penyebab tawuran karena persoalan sepele, karena hanya saling ledek pada saat hiburan hajatan, akhirnya penduduk saling menyerang". Kasus tawuran ini lanjutan dari tawuran sebelumnya.

Wakapolres mengambil kebijakan sementara pembekuan izin acara hiburan malam hari, dan hanya mengizinkan siang hari. Kebijakan ini diprotes para seniman dan warga masyarakat, karena dinilai merugikan dan menyebabkan penghasilan para seniman menurun drastis.

Sehubungan dengan intensnya konflik, bahkan pernah dalam satu malam ada 13 kejadian tawuran, sehingga Polres kehabisan petugas untuk mengamankannya. Bahkan polisi sampai kelelahan, sebagaimana dinyatakan Kapolres (S) :

"Satuan polisi kelelahan mengatasi Kamtibmas di daerahnya akibat tawuran, tidak bisa istirahat, saya belum tidur, habis bagaimana baru pulang pukul dua semalam, paginya ada tawuran lagi di Pekandangan".

Wakapolres mengambil kebijakan sementara pembekuan izin acara hiburan malam hari, dan hanya mengizinkan siang hari. Kebijakan ini diprotes para seniman dan warga masyarakat, karena dinilai merugikan yang menyebabkan penghasilan para seniman menurun drastis.

Konflik di Kecamatan Anjatan (Kabupaten Indramayau) dan Kecamatan Compreng (Subang) : Antar warga Desa Bugis Tua Kecamatan Anjatan Indramayu dengan warga Desa Kiarasari dan Jatireja Kecamatan Compreng Subang (merupakan konflik lintas Kabupaten karena warga desa yang terlibat konflik ada di perbatasan antara Kabupaten Indramayu dan Subang).

Kronologinya :

Pada hari Selasa sampai Rabu pagi tanggal 26-27 J uni tahun 2001, telah terjadi tawuran antar Desa yang dibatasi oleh sungai Cipunagara, dimulai dari perselisihan tindak kriminal antar pemuda yang mengakibatkan korban seorang warga Bugis Tua; Hal ini menimbulkan rasa dendam, selanjutnya dengan penyerangan oleh ratusan warga Bugis Tua beserta orang sewaan dari desa lain terhadap warga Desa Kiarasari dan Jatireja yang dituduh sebagai pelaku penganiyaan, termasuk menimbulkan kerusakan rumah dan harta benda dengan nilai 800 juta rupiah. Saling dendam ini dilanjutkan dengan saling merusak sawah yang ada di desanya masing-masing dan menutup lalau lintas jembatan yang menghubungkan ketiga yang berbatasan tersebut. 
Berdasarkan data konflik tawuran tampak kejadiannya sebagai berikut

Tabel. 1. Konflik tawuran dan penyelesaiannya di Kabupaten Indramayu dan Subang Tahun 1999-2004

\begin{tabular}{|c|c|c|c|c|c|c|c|}
\hline No & $\begin{array}{l}\text { Lokasi/ } \\
\text { Kecamatan }\end{array}$ & $\begin{array}{l}\text { Waktu/ } \\
\text { Tahun } \\
\text { Kejadian }\end{array}$ & $\begin{array}{l}\text { Penyebab/ } \\
\text { Media Konflik }\end{array}$ & $\begin{array}{l}\text { Korban } \\
\text { Te } \\
\text { was }\end{array}$ & $\begin{array}{l}\text { Korban } \\
\text { Luka } \\
\text { Bacok }\end{array}$ & $\begin{array}{l}\text { Kerugi } \\
\text { an } \\
\text { Rumah } \\
\text { Rusak/ } \\
\text { Dibakar }\end{array}$ & $\begin{array}{l}\text { Penyelesaian Konflik } \\
\text { Oleh Aparat/Inisiatif } \\
\text { Lokal }\end{array}$ \\
\hline 1 & Karangampel & 1999 & Hajatan/organ t. & - & 1 & 26 & Pengamanan Pol. \\
\hline 2 & Bongas & 2001 & Lempar batu & - & - & 5 & Pengamanan Pol. \\
\hline 3 & Lohbener & 2001 & Pemalakan & 1 & - & 18 & Pengamanan Pol. \\
\hline 4 & Indramayu & 2001 & Perselisihan & - & - & - & Pengamanan Pol. \\
\hline 5 & Anjatan & 2001 & Perselisihan & 1 & - & 20 & Sweeping Pol. \\
\hline 6 & Kandanghaur & 2002 & Hajatan/organ t. & - & 15 & - & Fatwa/Kesepakt. \\
\hline 7 & Gabuswetan & 2002 & Hajatan/organ t. & - & - & - & Kesepakatan \\
\hline 8 & Gabuswetan & 2002 & Hajatan/organ t. & - & - & . & I krar Bersama \\
\hline 9 & $\begin{array}{l}\text { Sliyeg } \\
\text { Arahan/ }\end{array}$ & 2002 & Hajatan/organ t. & - & 1 & 2 & $\begin{array}{l}\text { Memasang Bendera } \\
\text { putih }\end{array}$ \\
\hline 10 & Catinggi & 2002 & Hajatan/organ t. & - & - & 59 & Sweeping Pol \\
\hline 11 & Losarang & 2002 & Hajatan/wayang & - & . & - & nanan Pol. \\
\hline 12 & Cikedung & 2002 & Hajatan & - & - & 7 & Pengamanan Pol. \\
\hline 13 & Anjatan & 2001 & Tindak kriminal & - & - & Sawah & Pengamanan Pol. \\
\hline 14 & Compreng & 2001 & Tindak kriminal & - & 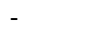 & Sawah & Pengamanan Pol. \\
\hline 15 & Lelea & 2004 & Hajatan/organ t. & & 1 & - & Pengamanan Pol. \\
\hline
\end{tabular}

Catatan: Konflik tawuran juga terjadi masing-masing satu kali pada tahun 1999 di kecamatan Karangampel dan tahun 2004 di kecamatan Lelea.

\section{Dasar Dasar Konflik}

Dari data kasus konflik tawuran tampak bahwa kerangka konseptual mekanisme konflik yang terjadi di pedesaan antar desa atau antar kampung (Blok), sifatnya dapat mikro atau makro sosiologis. Mikro sosiologis berkaitan dengan interaksi tipikal, sedangkan makro sosiologis berkaitan dengan aspek struktural masyarakat pedesaan. Aspek nilai akan berkaitan dengan mikro subyektif dan makro obyektif. Sebagaimana di ungkapkan Collins (1975), bahwa untuk mengetahui dasar-dasar atau akar masalah konflik dari fakta yang ada, maka konflik tersebut dapat dielaborasi dari berbagai aspek sosiologis sebagai berikut.

Mekanisme Konflik: Konflik yang terjadi antar warga pada umumnya dimulai dari interaksi antar dua kelompok pemuda dan ada juga remaja yang tingkat pendidikan dan ekonominya rendah (hanya SD bahkan banyak yang tidak tamat SD dan sebagian ada yang SLP dan SLA) yang sikap dan perilakunya ada kesamaan. Konflik yang terjadi ada pada stratifikasi kelas sosial ekonomi rendah. Konflik yang terjadi umumnya "difasilitasi" oleh adanya acara hiburan penyelenggaraan hajat. Tidak ada perebutan sumber daya yang sifatnya terbatas, yang ada adalah fenomena kultural adu gengsi dan pertunjukan ingin mendapat perhatian dan pujian. Hal ini terjadi pada saat hiburan ada acara "saweran", yaitu acara curahan hati (mencuri perhatian), bersaing siapa yang paling diperhatikan oleh biduan atau artis dangdut. Hal demikian masih berkaitan dengan tradisi seni 
tari ronggeng atau dompret yang dipertunjukan, seperti bersaing menggaet teman penari dengan lembaran uang.

Tujuan Konflik. Konflik yang terjadi dikaji dari segi tujuannya, tampaknya sangat kompleks dan multidimensi, tujuannya tidak dalam rangka pemeliharaan proses atau pengaturan solidaritas; Tetapi juga bertujuan integrasi dan pembebasan diri, tujuan mempertahankan gengsi dan harga diri serta tujuan penghancuran. Konflik yang terjadi ada proses integrasi antara pemuda sekampung atau sedesa, yang secara genealogis ada ikatan kerabat, bahkan diikat oleh tradisi kerjasama seperti "buwuhan", sebagai pola sosial saling membantu dalam memenuhi kebutuhan pokok seperti hajatan atau musibah yang cenderung pamrih, artinya "minta balasan" (ditemukan di Kecamatan Sliyeg).

Penyebab timbulnya konflik. Konflik antar pemuda pada saat acara hiburan merupakan fenomena yang paling utama., sehingga tawuran terjadi dipicu oleh bagian dari unsur sistem yang ada dalam hiburan acara hajatan. Jenis hiburan tarling dangdut, organ tunggal, dangdut dan sejenisnya acaranya selalu disertai acara pesan lagu dan ucapan yang dipandu MC atau biduannya. Terkadang cara memandu acara tersebut mendorong atau memancing adanya persaingan antar kelompok pemuda, sebagai akibat perkataan dalam ucapan minta lagu atau dari besarnya uang "saweran" (seperti kasus di Gabus Wetan). Adanya kelompok pemuda yang dikalahkan atau direndahkan prestisenya, menyebabkan salah satu kelompok pemuda menjadi merasa tersubordinasi pada acara hiburan dan mengalami ketidaksamaan (inequality) legitimasi, menimbulkan suasana emosi, hati panas sehingga pada saat bubar atau saat berpapasan pulang di jalan berubah suasana persaingan dan emosi atau panas menjadi konflik tawuran massal.

Pada kasus tawuran di desa Tugu (Sliyeg), selain akibat masalah prestise atau harga diri yang terusik, juga dikondisikan dengan warga masyarakat pemuda penganggur yang tidak mempunyai penghasilan. Tokoh setempat menduga ada kemungkinan lingkungan yang tidak kondusif, yang menjadikan suasana penuh kecemburuan sosial ekonomi. Ternyata ada pemikiran bahwa untuk menyelesaikan konflik dengan cara merekrut tenaga buruh pemuda dari daerah Tugu yang dipekerjakan di PT. Balongan.

Karakteristik konflik tawuran massal: Karakteristik konflik yang terjadi pada umumnya berkaitan dengan perasaan tidak senang akibat hal sepele seperti tersenggol atau ada ucapan kurang pas dari pembawa acara pada saat saweran, karena memandang yang dianggap menantang, yang mengakibatkan meningkatnya emosi. Tawuran lebih didorong oleh perasaan emosional yang selalu ingin membalas dendam untuk tujuan kepuasan emosi, sehingga tidak ada tujuan konflik yang spesifik. Maraknya tawuran dan cepatnya eskalasi konflik tawuran hanya sekedar simbol ekspresif perasaan tidak senang, tetapi tidak mempunyai tujuan yang spesifik dari tawuran yang dilakukannya. Ada suatu hal yang menarik dari karakteristik konflik tawuran yang terjadi, yaitu 
(a) Konflik tawuran yang terjadi pada sekitar bulan Mei, Juni dan September, yaitu setelah musim panen, tidak ada pekerjaan lain.

(b) Konflik tawuran meledak sebelum, saat atau sesudah acara hiburan hajatan pernikahan atau sunatan, atau saat suasana banyak orang atau kerumunan orang.

(c) Pemuda yang berselisih kemudian bertawuran missal, ada indikasi sedang mabuk (minuman keras).

(d) Karakteristik aktor tawuran pada umumnya berlatar belakang pendidikan SD

(e) Tindakan tawuran bersifat acak, artinya apa saja benda yang dapat dijadikan sebagai pelampisan rasa kekesalan atau dendam dirusak, seperti rumah, kendaraan, jembatan, alat penerangan umum, balai desa, sawah dan sarana lainnya yang kebetulan dilewati pelaku tawuran.

(f) Tampak bahwa konflik yang terjadi dimulai dari persoalan pribadi kemudian merembet ke tawuran massal antar kelompok atau antar desa atas dasar rasa solidaritas.

Model Resolusi Konflik:

Model resolusi konflik yang telah dilakukan dengan pengamanan polisi, penyisiran (sweeping), ikrar bersama (brayan), kesepakatan dan pasang bendera putih sebagai simbol damai.

\section{SI MPULAN DAN REKOMENDASI simpulan}

Akar masalah konflik tawuran antar kampung (blok) dan antar desa di wilayah Pantura (wilayah kabupaten Indramayu dan kabupaten Subang), menunjukkan bahwa : Pertama, konflik tawuran akar masalahnya adalah adanya persyaratan kondisi yang mencukupi (sufficiency condition) terjadinya konflik, yaitu kebiasaan minum minuman keras pada saat hiburan hajatan, yang terlembagakan oleh nilai sosial budaya yang dikemas dalam kesenian tradisional. Kedua, akibat krisis identitas dan harga diri yang menuntut banyak perhatian orang lain. Ketiga, konflik dalam Pilkades (pemilihan kepala desa) disebabkan adanya kontradiksi yang tajam dalam orientasi nilai sosial kepemimpinan, yang berkembang menjadi stereotip, kemudian muncul sikap emosional, yang disusul perilaku obyektif struktural saling menyerang.

Nilai tradisi masyarakat dalam bentuk seni telah hilang pemaknaan positifnya sehingga potensial untuk konflik, seperti tradisi ngarot, kuda lumping, sempiong, satron/koprokan dan ujungan. Nilai sosial budaya lokal yang dapat dijadikan sebagai media penyelesaian konflik adalah brayan dan buwuhan.

Nilai sosial budaya (tradisi ritual dan seni) memiliki potensi sebagai modal sosial karena sifatnya dapat memotivasi dan menumbuhkan perdamaian serta kondusif menggalang dan menumbuhkan kerjasama, tanggungjawab, menyelesaikan masalah bersama, meluaskan jaringan hubungan sosial, rasa solidaritas sosial dan kejujuran, seperti tampak pada buwuhan, ngarot, 
nadran/seba laut, mapag Dewi Sri, ruatan bumi, doger kontrak, dompret dan banjet.

\section{Rekomendasi}

Pemeritah dan masyarakat secara bersama-sama mengembangkan nilai sosial budaya kondusif damai dan potensi modal sosial, dengan cara melakukan reaktualisasi dan revitalisasi ritual dan kesenian tradisonal dengan pemaknaan yang rasional, obyektif, religius dan profesional. Hasil penelitian ini menjadi informasi dasar untuk penelitian lanjutan tentang model resolusi konflik dan pemberdayaan modal sosial melalui kajian nilai sosial budaya lokal dan melalui pendidikan damai.

\section{DAFTAR PUSTAKA}

Boulding. (1989). Three Peace of Power, Sage Publ. Newbury Park.

Cahyono, H. (2005). (Ed)., Konflik Elit Politik Pedesaan, Pustaka Pelajar dan LIPI Jakarta

Coleman, J. S. (2000). Social Capital in The Creation of Capital in The Creation of Human Capital. The World Bank Washington DC (p.13)

Collins, R. (1975). Conflict Sociology, New York Academic Press.

Eldridge J.E.T. (1980) Max Weber The Interpretation of Social Reality. Schocken Books New York.

Fukuyama, F. (1995). Trust: The Social Vertue and The Creation of Prosperity. New York Free Press.

Galtung, J . (1980). The True World: Tansnational Pespective, The Free Press, New York

Kusnadi (2002). Konflik Sosial Nelayan. LKIS J akarta

Lawrence, N. W. (1997). Social Research Merthods. Allyn and Bacon, Boston

Miall, R., dan Haouse, W. (2000), Resolusi Damai Konflik Kontemporer, Trj. Satrio,

Raja Grapindo Persada J akarta. hal. 7-33

Putnam, R. (1993). The Prosperous Community, Social Capital and Public Life. The American Prospect, (pp.13-65-78)

Raymond, A. (1965). Main Currents In Sociological Thought II, Terj. Howard R. dan Weaver H., Anchor 
Sztompka , P. (1992), Trust and Emerging Democracy, Jagiellonian University, Krakow.

Turner, J . (1991). The Structure of Sociological Theory, Wardworth Publising Company California.

Wendy. S. (2001). Measuring Social Capital, Research Paper, no. 24, February 2001, Australian Institute of Family Studies. Hal.7-9.

Wolff, K. H. (1964). The Sociology of George Simmel, The Free Press, New York, 1964, hal. 230.

Woolcock. (2001). The Place of Social Capital in Understand Social and Economic

Outcame .Canadian J ournal of Policy Research Isuma:Vol2:1 p Spring hlm.11-17

\section{Terbitan Pemda/ Berita Harian Umum}

Bappeda dan BPS. (2002). Indramayu dalam Angka, Bappeda Kab. Indramayu

Bappeda. (2002). Kabupaten Indramayu Selayang Pandang. Bappeda

Bappeda dan BPS. (2003). Subang dalam Angka. BPS Kab. Subang

Disbupar. (2003). Deskripsi Pendokumentasian Nilai-nilai Tradsional di Kabupaten Subang. Kab Subang

Harian Pikiran Rakyat. (2004). Informasi Masyarakat Jawa Barat terbitan 19982004

Supardi, I. (2005). Doger Kontrak. Disbupar. Kab. DT.II Subang

Pemda. DT II I ndramayu. (2002). Sejarah Indramayu. Pemda Kab. Indramayu

Kantor Disbupar. (2004). Sejarah Desa Lelea. Pemda Indramayu 